INTEGRITAS : Jurnal Pengabdian

Vol 3, No 2, Desember 2019

ISSN 2580-7978 (Cetak) ISSN 2615-0794 (Online)

\title{
PKM PELATIHAN PEMBUATAN PRODUK CINDERAMATA ACRILIC BERBAHAN DASAR LIMBAH KAYU GMELINA DAN PEMASARAN ONLINE PADA KELOMPOK USAHA BERSAMA (KUB) SEKAR PUTIH SITUBONDO
}

\section{PKM TRAINING IN MAKING ACRILIC SOUVENIRS MADE OF GMELINA WOOD WASTE AND ONLINE MARKETING FOR JOINT BUSINESS GROUP (KUB) SEKAR PUTIH SITUBONDO}

\author{
Edy Kusnadi Hamdun \\ Manajemen, Fakultas Pertanian, Universitas Abdurachman Saleh Situbondo \\ Email : Edykoko_1134@yahoo.com
}

\begin{abstract}
Produk cindera mata acrilic memiliki nilai ekonomi yang tinggi, dimana harga kisaran yang ditawarkan di pasar mencapai ratusan ribu rupiah. Banyaknya limbah meuble di wilayah Situbondo, utamanya kayu gmelina cukup menjadi peluang untuk bisa dijadikan produk-produk kerajinan seperti cinderamata. Mitra yang terlibat dalam kegiatan ini adalah Kelompok Usaha Bersama (KUB) "Sekar Putih", Kelompok usaha ini merupakan perkumpulan masyarakat yang akan memulai wirausaha pengolahan limbah kayu gmelina menjadi produk cinderamata acrilic. Kegiatan ini memberikan pembinaan bagi KUB "Sekar Putih" untuk berkembang cepat hingga mampu menciptakan produk yang inovatif dan pola pasar baru sehingga mampu menghadapi persaingan di era digital. Hasil luaran dari kegiatan ini berupa jasa, model, metode, system, produk/barang, dan paten. Luaran lain yang ingin dicapai adalah menumbuhkan wirausaha yang maju dan berinovatif, meningkatkan pengetahuan tentang pemanfaatan limbah kayu, menciptakan produk cinderamata acrilic yang unik dan modern, meningkatkan pengetahuan pemasaran online dengan media $e$-commerce dan sosial media sehingga meningkatkan pangsa pasar produknya, dan meningkatkan pendapatan dan kesejahteraan keluarga anggota KUB "Sekar Putih".
\end{abstract}

Kata Kunci : Pemberdayaan, Limbah Kayu gmelina, Pemasaran

Abstract : Acrylic souvenir products have high economic value, where the price range offered on the market reaches hundreds of thousands of rupiah. The large amount of furniture waste in Situbondo area, especially gmelina wood, is quite an opportunity to be made into handicraft products such as souvenirs. The partner of this activity is Joint Business Group (KUB) "Sekar Putih". This business group is a community association that will start the entrepreneurship of processing gmelina wood waste into acrylic souvenir products. This activity provides guidance for KUB "Sekar Putih" to develop rapidly and to be able to create innovative products and new market patterns so that they can face competition in 


\section{INTEGRITAS : Jurnal Pengabdian}

Vol 3, No 2, Desember 2019

ISSN 2580-7978 (Cetak) ISSN 2615-0794 (Online)

the digital age. The outputs from this activity are services, models, methods, systems, products / goods, and patents. Other outcomes to be achieved are growing and innovative entrepreneurs, increasing knowledge about the utilization of wood waste, creating unique and modern acrylic souvenir products, increasing online marketing knowledge with e-commerce media and social media so as to increase the market share of its products, and increasing revenue and the welfare of the KUB member family "Sekar Putih".

Keywords: Gmelina Wood Waste, Marketing, training

\section{PENDAHULUAN}

Kabupaten Situbondo merupakan salah satu Kabupaten yang adan di Jawa Timur, yang terkenal dengan sentra produk-produk kerajinan hasil kreasi UMKM masyarakat. Saat ini Situbondo tercatat telah memiliki UMKM sebanyak 13.107 pada tahun 2017 (Disperindag Situbondo 2017). Produk-produk tersebut diantaranya Cinderamata, Merchandise, souvenir, furniture, anyaman dan surfingdan produk-produk lainnya. Peluang bisnis olahan kayu tersebut sangat memiliki prospek baik kedepannya, terlihat dari banyaknya permintaan pasar pada produk ini. Tingginya kebutuhan masyarakat akan produk-produk kerajinan dari kayu terlihat pada beberapa pasar elektronik. Produk cinderamata merupakan produk yang dapat digunakan sebagai oleh-oleh atau penghargaan yang diperoleh secara khusus sebagai kenang-kenangan. Produk ini cukup memiliki nilai ekonomi yang tinggi, dimana harga kisaran yang ditawarkan di pasar mencapai ratusan ribu rupiah. Banyaknya limbah meuble di wilayah Situbondo, utamanya kayu gmelina cukup menjadi peluang untuk bisa dijadikan produk-produk kerajinan seperti cinderamata. Produk ini berbahan dasar limbah kayu dengan dipadukan dengan bahan dasar acrilic/kaca. Permintaan pasar yang tinggi dan nilai ekonomi yang besar membuat produk ini menjadi sasaran utama produksi pelaku UMKM khususnya di Kabupaten Situbondo.

Desa Trebungan merupakan salah satu desa yang ada di Kabupaten Situbondo, mayoritas UMKM yang ada di wilayah ini yaitu bergerak dalam 


\section{INTEGRITAS : Jurnal Pengabdian}

Vol 3, No 2, Desember 2019

ISSN 2580-7978 (Cetak) ISSN 2615-0794 (Online)

bidang meuble dan pertanian. Limbah yang dihasilkan rata-rata dimanfaatkan masyarakat sebagai bahan bakar kayu untuk memasak, hal ini tentu tidak menciptakan nilai tambah produk dan ekonomi bagi masyarakat. Rendahnyapengalaman, pemahaman dan kreatifitas masyarakat untuk memanfaatkan limbah kayu untuk menciptakan produk-produk kreatif, sehingga berdampak terhadap pendapatan masyarakat yang masih rendah.

\section{Permasalahan Mitra}

Permasalahan yang ditemukan dan solusi yang ditawarkan :

1. Rendahnya kreatifitas masyarakat untuk menciptakan produk

2. Minimnya pengetahuanakanprinsip efisiensi dan efektifitas dalam produksi sebuah produk kerajinan

3. Rendahnya pengetahuan untuk memasarkan produk, akibat ketidakmampuan memahami dunia teknologi dapat menghambat kemajuan usaha

4. Masyarakat cenderung menjadi pekerja dari pada sebagai pelaku industri.

5. Rendahnya pendapatan masyarakat desa Trebungan, ketergantungan pada usaha meuble besar dan bekerja sebatas sebagai pekerja borongan, sehingga pendapatan sangat tergantung pada tinggi rendahnya permintaan pasar pada meuble di sekitar.

6. Limbah kayu Gmelina yang melimpah

\section{SOLUSI DAN TARGET LUARAN}

Adapun solusi yang ditawarkan untuk"KUB" Sekar Putih agar mampu mengolah limbah kayu menjadi produk "Cinderamatan Acrilic" yaitu :

\section{PelatihanMetode Pemilihan Bahan Baku}

Kelompok usaha ini akan diberikan pemahaman bagaimana memilih limbah-limbah kayu yang dapat dijadikan beberapa jenis cinderamata, diantaranya dari segi ukuran, tekstur kayu, tingkat kekeringan/kadar air, warna, dan daya tahan; 
INTEGRITAS : Jurnal Pengabdian

Vol 3, No 2, Desember 2019

ISSN 2580-7978 (Cetak) ISSN 2615-0794 (Online)

\section{Pelatihan Pelatihan Produksi Cinderamatan Acrilic}

Pada tahapan ini, kelompok usaha bersama "Sekar Putih" diberikan pelatihan teknis Pemotongan kayu, Penghalusan, pengkombinasian, dan Finishing produk Cinderamatan Acrilic.

\section{Pelatihan Pemasaran Online}

anggota KUB Sekar Putih ini akan diberikan pelatihan pemasaran menggunakan dua media yaitu :
a. E-commerce,
b. Sosial Media

\section{Evaluasi Hasil Kegiatan Pelatihan dan Pendampingan}

Hasil pelatihan akan diberikan pendampingan dan evaluasi untuk mendukung tercapainya wirausaha yang mandiri, kreatif dan inovatif serta mampu menggunakan teknologi dengan baik.

\section{Luaran}

1. MenumbuhkanJiwa wirausahaan yang maju dan berinovatif;

2. Meningkatkan pengetahuanpemanfaatan limbah kayu

3. Menciptakan produk cinderamata acrilic yang unik dan modern;

4. Meningkatkan pengetahuan pemasaran online dengan media $e$ commercedan sosial media sehingga meningkatkan pangsa pasar produknya;

5. Meningkatkan pendapatan dan kesejahteraan keluarga anggota KUB "Sekar putih".

\section{HASIL DAN LUARAN YANG DICAPAI}

\section{Pelatihan Pembuatan Produk (Produksi dari limbah)}

Pengembangan proses produksi untuk produk-produk limbah berbahan dasar kayu gmelina, harus didasari dengan perencanaan perhitungan yang baik agar hasil produksi bisa menghasilkan kualitas yang baik, efektif dalam pembuatan dan efisien dari segi biaya. Tingginya persaingan bisnis kreatif khususnya produk cinderamata membuat para pelaku bisnis ini mulai bersaing 


\section{INTEGRITAS : Jurnal Pengabdian}

Vol 3, No 2, Desember 2019

ISSN 2580-7978 (Cetak) ISSN 2615-0794 (Online)

dari segi harga, disamping dampaknya pada kualitas produknyanya yang akan menurun pula. Perlunya langkah yang baik agar terciptanya produk yang berkualitas dan memiliki jangkauan pasar yang besar hingga ke seluruh negeri. Berikut merupakan hasil produk cinderamatan yang telah dihasilkan :

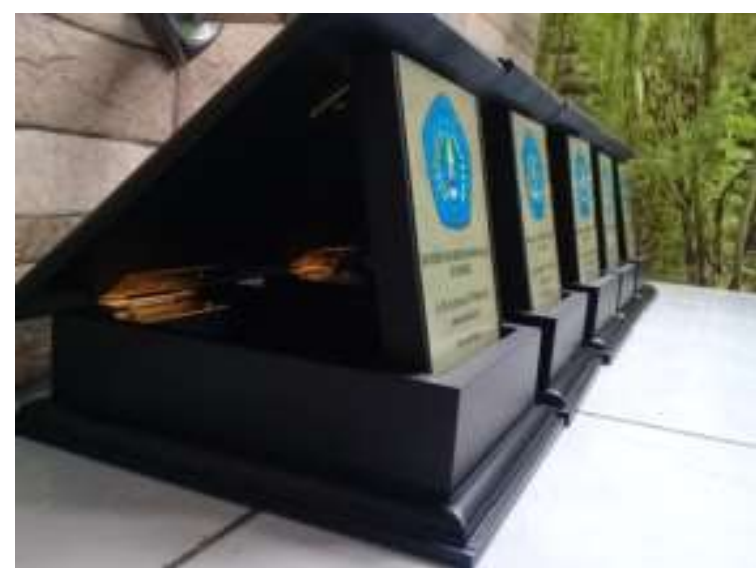

Gambar 1. Hasil kreasi produk berbahan dasar Limbah Kayu

Sebelum melaksanakan tahaan pembuatan produk, untuk bisa meningkatkan efektifitas dan efisiensi produksi dilakukan dengan langkah-langkah dibawah ini:

\section{1) Proses Pemilihan Bahan Baku Kayu Limbah}

Memilih bahan baku dilakukan untuk memastikan bahan baku (limbah kayu) merupakan bahan yang masih bisa dimanfaatkan dan memiliki kualitas baik, pemilihan kayu yang salah dapat mengakibatkan rendahnya kualitas cinderamata acrilic ini. Karena Pemilihan kayu ini harus disesuaikan dengan kebutuhan ukuran kayu dan desain produk cinseramata yang akan dibuat.Jika ukuran limbah terlalu besar sedangkan kebutuhannya yang kecil, akan menjadikan kayu terbuang sia-sia atau menjadi limbah kembali. Saat ini ketersediaan limbah kayu gmelina banyak tersedia, karena limbah yang dihasilkan beberapa usaha meuble di wilayah Desa Trebungan yang cukup banyak, kayu ini sangat sesuai 


\section{INTEGRITAS : Jurnal Pengabdian}

dengan produk Cinderamata Acrilic ini, karena memiliki tekstur yang halus dan memiliki tingkat keawetan seperti kayu jati.

\section{2) Tahap Pemotongan Kayu}

Tahap pemotongan kayu limbah menggunakan mesin dinamo pemotong, jika dibandingkan dengan menggunakan gergaji biasa, maka lebih tidak efisien dalam pengerjaan. Penggunaan mesin pemotong ini akan lebih menghasilkan bentuk kayu yang lurus dan halus, kayu yang termakan oleh mata gergaji jumlahnya lebih sedikit sangat kecil. Bentuk dari cinderamata ini yaitu persegi dan

\section{3) Tahap Pengeringan Kayu}

Tahap pengeringan limbah kayu untuk memastikan hasilnya nanti tidak merusak tekstur kayu, hal ini dapat dilakukan dengan tiga cara pengerjaan, diantaranya :

a) Dijemur di bawah terik matahari

Penjemuran dengan sistem ini akan membuat kayu lebih lunak dikarenakan, proses pengeringan akan lebih cepat, namun harusdilakukan secara benar untuk menghindari pecahnya kayu akibat suhu terlalu panas.

b) Melalui Oven Pengering

Cara pengeringan ini dapat dilakukan sebagai pengganti matahari, biasanya dilakukan ketika musim penghujan, namun penggunaan oven akan membuat biaya tambahan yang lebih besar, selain hasil pengeringan yang cepat namun masih lebih baik dilakukan dengan penjemuran matahari.

c) Didiamkan di tempat yang dingin dengan durasi yang lama Pengeringan di tempat dingin ini membutuhkan waktu yang cukup lama, sekitar satu bulan lamanya, namun dilihat dari segi kualitas, hasil pengeringan secara alami ini lebih baik untuk membuat struktur kayu lebih padat dan cara ini sangat baik untuk dijadikan produk-produk cinderamata. 


\section{INTEGRITAS : Jurnal Pengabdian}

\section{4) Persiapan Peralatan Produksi}

Pemilihan alat produksi menjadi penting untuk memastikan setiap proses produksi akan menjadi lebih efektif dan efisien, selain itu dari kualitas akan lebih baik dan terjamin, beberapa peralatan yang dibutuhkan untuk produksi cinseramata acrilic yaitu :
a) Mesin Grinda pemotong
b) Mesin Penghalus duduk
c) Mesin Grinda Penghalus
d) Mesin Bor
e) Mesin Pemotong Scroll Saw
f) Mesin Router
g) Mesin Serut
h) Kompressor

\section{5) Proses Pelatihan Pembuatan Produk Cinderamata Acrilic}

Pelatihan Pembuatan produk ini dilakukan setelah kayu limbah telah dinyatakan kering, bahan baku yang kering tersebut kemudian dilakukan Proses Pemotongan, penghalusan dan Pengeleman. Pemetaan kayu juga diperlukan sebagai dasar untuk menentukan penggunaan bahan baku masing-masing jenis Cinderamata Acrilic yang akan dibuat, hal ini dilakukan untuk memanfaatkan kayu sesuai kebutuhan masing-masing jenis produk. Sebagai contoh untuk papan dijadikan sebagai alas dan bagian atas produk ini. Selanjutnya adalah proses pemotongan, proses pemotongan ini dilakukan dengan mesin pemotong kayu, menggunakan ukuran yang ditetapkan kemudian dilanjutkan dengan proses penghalusan menggunakan mesin serut kayu dan mesin router untuk membuat pola pojok kayu Pada tahapan ini dilakukan secara hati-hati, agar hasilnya sesuai dengan kualitas produk yang ingin dicapai. Para Peserta pelatihan telah mampu melakukan proses ini hingga tahapan penghalusan kayu. Selanjutnya tahapannya adalah pemotongan kayu. Bahan yang telah dipotong kemudian dihaluskan menggunakan alat peralatan dinamo 


\section{INTEGRITAS : Jurnal Pengabdian}

penghalus. Selanjutnya dilakukan tahapan pewarnaan kayu, dimana pada tahapan ini dilakukan secara berulang-ulang untuk menghasilkan tekstur kayu yang halus. proses finishing ini harus dilakukan secara hati-hati untuk memastikan permukaan produk cinderamata menjadi halus tanpai pori-pori. Proses finishing umumnya dilakukan sebanyak 5 kali menggunakan media cat minyak maupun dengan cat dengan campuran air. Proses juga ditambah dengan bahan dempul untuk menutup pori-pori kayu menjadi lebih datar. Tahap akhir yaitu pemasangan engsel, pemasangan papan acrilic pada bagian depan dan menyatukan seluruh bagian-bagian yang telah selesai dibuat. Setelah seluruh bagian terpasang, maka tinggal dikeringkan kembali dalam 5 jam, hasilnya seperti dibawah

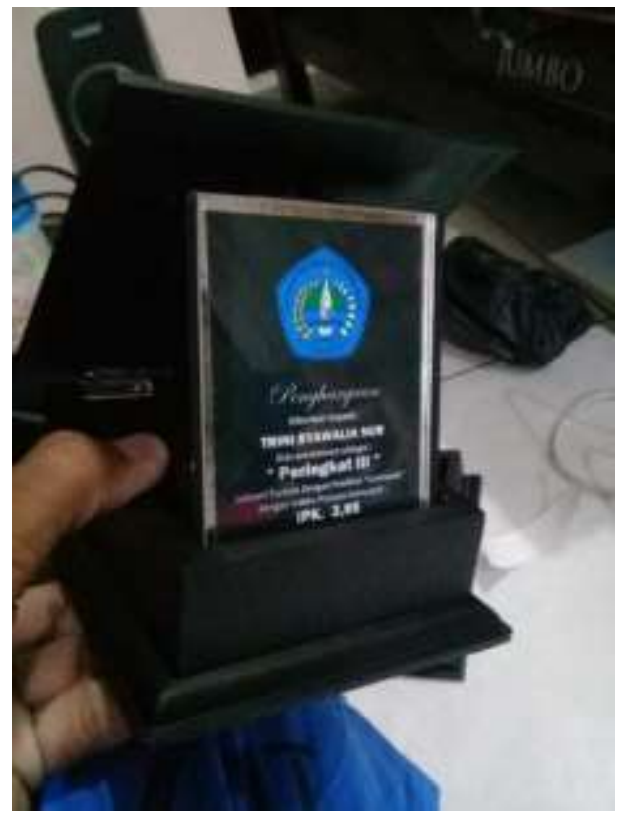

Gambar 2. Hasil Produk Pengabdian

\section{B. Pelatihan Pemasaran Berbasis Online}

Pendampingan pengembangan pemasaran bagi Kelompok Usaha Bersama (KUB) Sekar Putih Situbondo juga diberikan untuk memastikan produknya bisa dipasarkan secara nasional. Melalui beberapa e-commerce indonesia seperti Shopee, Bukalapak, dan Tokopedia. Perkembangan e-commerce indonesia 


\section{INTEGRITAS : Jurnal Pengabdian}

Vol 3, No 2, Desember 2019

ISSN 2580-7978 (Cetak) ISSN 2615-0794 (Online)

didukung penuh oleh tingginya promosi yang dilakukan, menggunakan endorser, melalui media televisi maupun sosial media dan media cetak. Maraknya promosi yang dilakukan secara besar-besaran ini membuat pemahaman masyarakat tentang apa itu ecommerce menjadi tinggi. Didukung dengan adanya jaminan dan gratis biaya pengiriman, ketertarikan semakin tinggi untuk mencoba berbelanja online.

Berkembangnya sektor transaksi elektronik dari sistem pembayaran digital perusahaan franchise seperti indomart, jasa perbankan yaitu e-banking menjadi dongkrak utama yang bisa memberikan kemudahan bertransaksi bagi seluruh konsumen dan produsen online khususnya pelaku usaha cinderamata di Indonesia. Pebayaran produk yang dibeli kemudian dapat dilakukan dimana saja dan kapanpun, disamping itu juga jaminan-jaminan Keamanan transaksi yang diberikan membuat perasaan hawatir untuk ditipu menjadi berkurang. Brikut model transaksi melalui e-commerce antara penjual dan pembeli :

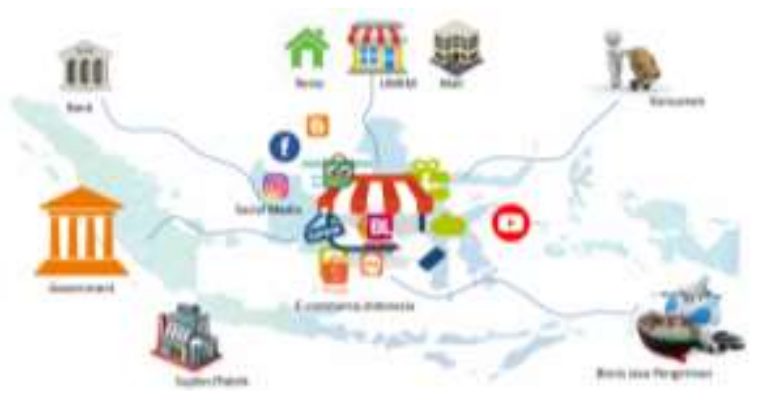

Gambar 3. Framework e-commerce

Manfaat yang bisa diambil oleh Kelompok Usaha Bersama (KUB) Sekar Putih Situbondoini tersebut dalam pemasaran diantaranya :

1. Model produk, yaitu bagaimana model suatu produk agar menarik perhatian konsumen untuk membelinya, hal yang terkandung dalam model ini termasuk bentuk cinderamata yang inovatif menjadi beberapa macam bentuk terbaru atau berbeda dengan yang lainnya.

2. Harga jual produk, yaitu dengan menyesuaikan antara total biaya produksi dan laba yang direncanakan maka akan mengetahui harga jual produk yang sesungguhnya kemudian untuk menjadi pertimbangan apakah harga yang 


\section{INTEGRITAS : Jurnal Pengabdian}

Vol 3, No 2, Desember 2019

ISSN 2580-7978 (Cetak) ISSN 2615-0794 (Online)

ditawarkan bisa bersaing di pasar atau tidak. Harga jual produk cinderamata pada umumnya dikisaran Rp. 150.000 s.d Rp. 200.000,-

3. Promosi, yaitu langkah untuk memperkenalkan produk kepada masyarakat. Langkah pemanfaatan tekhnologi adalah yang paling tepat, media pemasaran online sangat membantu untuk mempercepat proses pemasaran produk. Beberapa cara pemasaran yang diajarkan diantaranya yaitu dengan media sosial facebook, Instagram, Whatsapp. Sedangkan media untuk bertransaksi, anggota Kelompok Usaha Bersama (KUB) Sekar Putih diberikan pemahaman membuka toko online di Bukalapak, tokopedia dan shopee.

4. Distribusi, yaitu bagaimana membuat produk bisa sampai pada konsumen, penjualan bisa dengan cara directselling atau penjualan langsung dan bisa juga dengan agen. Langkah-langkah pengenalan produk dengan cara langsung tersebut merupakan hal yang paling mudah untuk dilaksanakan bagi usaha-usaha di masyarakat yang kemudian akan semakin dikenal dan diminati oleh masyarakat banyak. Jika menggunakan media penjualan online maka jasa pengiriman dibutuhkan seperti JNE, J\&T dan Pos Indonesia.

Setelah semua pelatihan selesai para para pelaku usaha dapat mencoba mempraktekkan cara tersebut pada bisnis masing-masing, diharapkan berawal dari pendampingan proses pembuatannya hingga selesai, bisa meningkatkan omset penjualannya dan membuka lapangan pekerjaan baru di masyarakat dimasa mendatang. Masing-masing pelaku usaha wajib untuk membuat toko online di ketiga ecommerce tersebut, yang kemudian ditindaklanjuti dengan mengupload produk-produknya secara daring. Nantinya juga akan ditindaklanjuti dengan evaluasi hasil kegiatan perkembangan bisnisnya. 


\section{INTEGRITAS : Jurnal Pengabdian}

Vol 3, No 2, Desember 2019

ISSN 2580-7978 (Cetak) ISSN 2615-0794 (Online)

\section{Pendampingan Manajemen Keuangan}

Materi yang diberikan yaitu mengenai pengelolaan manajemen usaha mikro yaitu proses produksi dan keuangan, permasalahan yang sering terjadi bagi usahausaha kecil yang dimasyarakat juga menjadi pembahasan dalam pelatihan ini sebagai pedoman untuk meningkatkan jumlah wirausaha baru dan peningkatan pendapatan. Kegiatan ini diharapkan mampu untuk meningkatkan penjualan Produk Cinderamata di Kabupaten Situbondo sehingga bisa meningkatkan pendapatan keluarga dan menjadi industri rumah tangga yang handal dan dapat terus dikembangkan. Materi keuangan diarahkan untuk mengetahui tentang sumber permodalan usaha serta seberapa besar permodalan yang dibutuhkan untuk usaha tersebut, setelah mengetahui prosesnya maka diharapkan mampu untuk memulai manajemen usaha yang mandiri serta mampu mencatat keuangannya dari segi besar biaya dan pendapatan yang diperoleh untuk mengetahui apakah usahanya akan untung maupun rugi.

\section{Pendampingan tentang Hukum Bisnis}

Pelatihan tahap ini materi yang diberikan tentang pemasaran usaha dan bentuk-bentuk badan hukum serta persyaratan-persyaratan untuk pendiriannya. Untuk usaha perorangan bisa melakukan perijinan meskipun belum berbadan hukum UD atau PT. Oleh sebab itu melalui pelatihan ini diharapkan bisa meningkatkan kedisiplinan untuk mentaati peraturan tentang industri rumah tangga.

\section{E. Evaluasi Kegiatan}

Kegiatan evaluasi dilaksanakan sebagai monitoring atas hasil yang dicapai atas beberapa kegiatan sebelumnya apakah terdapat kendala yang dihadapi masing-masing peserta Kelompok Usaha Bersama (KUB) Sekar Putih Situbondo dalam melaksanakan proses produksi hingga pemasarannya. Kegiatan evaluasi ini sangat bermanfaat untuk mengukur kemampuan masing-masing peserta pengabdian dalam menyerap sehingga mempermudah proses pendampingan pada tahap berikutnya. 


\section{INTEGRITAS : Jurnal Pengabdian}

Vol 3, No 2, Desember 2019

ISSN 2580-7978 (Cetak) ISSN 2615-0794 (Online)

\section{F. Luaran Yang Dicapai}

Berikut luaran yang telah dicapai atas Program Kemitraan Masyarakat (PKM) ini khususnya bagi Kelompok Usaha Bersama (KUB) Sekar Putih Situbondoyaitu :

a) Menumbuhkan Jiwa wirausahaan yang maju dan berinovatif.

Inovasi menjadi penting agar mampu bertahan di era persaingan saat ini yang sangat cepat, jika mampu menyesuaikan makan akan bertahan dan tetap maju bisnisnya.

b) Meningkatkan pengetahuan pentingnya tekhnologi dalam usaha pengolahan kayu menjadi produk cinderamata

Tekhnologi menjadi penting karena indonesia saat ini telah memasuki revolusi industri 4.0, stimulus pemahaman perdagangan digital perlu dilakukan untuk menopang tingginya transaksi berbasis daring.

c) Meningkatkan pengetahuan pemasaran online dengan media e-commerce sehingga meningkatkan pangsa pasar produknya

Penjualan online sudah menjadi trend saat ini, untuk itu seluruh anggota Kelompok Usaha Bersama (KUB) Sekar Putih Situbondo ini telah memiliki kesiapan dan mampu untuk memasarkan produknya melalui ecommerce.

d) Meningkatkan kesejahteraan keluarga anggota kelompok Kelompok Usaha Bersama (KUB) Sekar Putih Situbondo

Dengan meningkatnya jaringan pemasaran melalui jaringan internet diharapkan nantinya akan berdampak terhadap perekonomian para pelaku industri tersebut. 


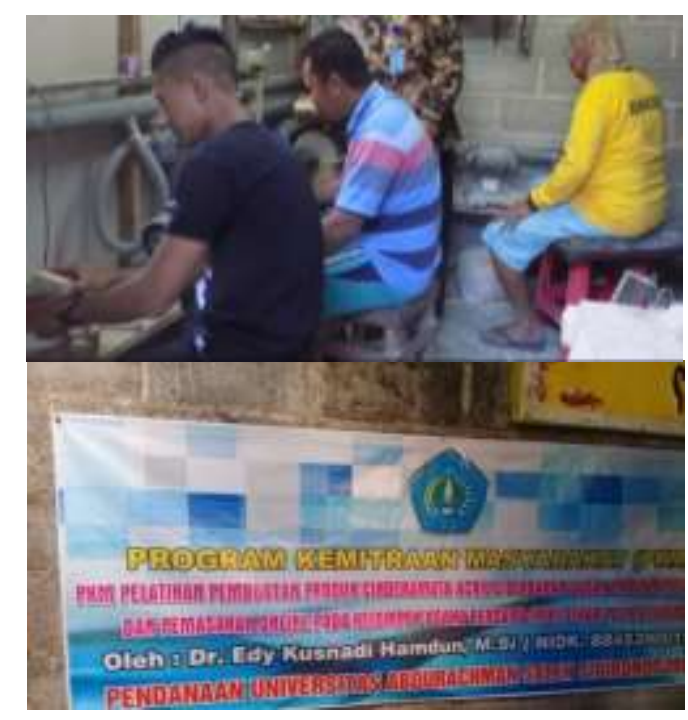

Gambar 6. Kegiatan Pengabdian

\section{KESIMPULAN DAN SARAN}

\section{A. Kesimpulan}

Kegiatan ini merupakan pembinaan dalam bentuk perbaruan metode produksi dan pemasaran dengan langkah yang lebih efektif dan efisien. Minimnya pengetahuan para pelaku usaha khususnya bagi Kelompok Usaha Bersama (KUB) Sekar Putih Situbondo untuk bisa menghasilkan produk berkualitas. Pembinaan ini dilakukan dengan melalui metode penerapan mesin produksi, pelatihan teknis pemotongan, penghalusan, dan finishing, pelatihan pemasaran berbasis digital dan pendampingan akhir. Luaran yang dihasilkan dari kegiatan ini adalah menumbuhkan jiwa wirausahaan yang maju dan berinovatif, meningkatkan pengetahuan pentingnya tekhnologi dalam usaha pengolahan kayu menjadi produk cinderamata, meningkatkan pengetahuan pemasaran online dengan media e-commerce sehingga meningkatkan pangsa pasar produknya, meningkatkan kesejahteraan keluarga anggota kelompok Kelompok Usaha Bersama (KUB) Sekar Putih Situbondo. 


\section{INTEGRITAS : Jurnal Pengabdian}

Vol 3, No 2, Desember 2019

ISSN 2580-7978 (Cetak) ISSN 2615-0794 (Online)

\section{B. Saran}

Saran yang bisa diberikan atas pelaksanaan Program Kemitraan Masyarakat (PKM) kepada Kelompok Usaha Bersama (KUB) Sekar Putih Situbondo yaitu :

1. Perlunya niat dan semangat untuk memulai usaha dan mengembangkannya khususnya produk cinderamata ini agar program peningkatan jiwa wirausaha menjadi terwujud dengan baik dan bisa menularkan pada anggota lainnya.

2. Untuk bisa mewujudkan menjadi seorang wirausahawan sejati, diperlukan kedisiplinan dan fleksibilitas dalam hal ide baru agar produk-produk yang dihasilkan mampu bersaing di pasar.

\section{DAFTAR PUSTAKA}

Abdullah, Maskur. 2005. Lilitan Masalah Usaha Mikro kecil, Menengah (UMKM) dan Kontroversi Kebijakan. Medan: Bitra Indonesia.

Anoraga, Panji. 2002. Koperasi, Kewirausahaan, dan Usaha Kecil. Jakarta: Rineka Cipta.

Departemen Perdagangan Republik Indonesia. 2008. Pengembangan Ekonomi Kreatif Indonesia 2025: Rencana Pengembangan Ekonomi Kreatif Indonesia 2009-2025. Jakarta: Departemen Perdagangan

Fuady, Munir, Pengantar Hukum Bisnis, (Bandung : PT.Citra Aditya Bakti, cetakan ke II, 2005)

Kotler, Philip, 2002, Manajemen Pemasaran, Jilid 2, Alih Bahasa oleh Hendra Teguh dkk, Edisi Milenium, Jakarta : PT Prenhallindo

Miftahus Sholihin, Siti Mujilahwati (2016), Dampak Pemanfaatan E-Commerce Terhadap Peningkatan Penjualan Di UMKM : Jurnal Teknika Vol. 8 No. 1 Maret 2016

Diyan Ivanov (2012) The impact of e-commerce on small-size companies in Swede : Karistad University : swedan

A Industri, Tokopedia.com Catat Pertumbuhan Transaksi 200\%. Diakses pada tangal 17 Desember 2017. http://industri.bisnis.com, E-COMMERCE: 
INTEGRITAS : Jurnal Pengabdian

Vol 3, No 2, Desember 2019

ISSN 2580-7978 (Cetak) ISSN 2615-0794 (Online)

Ann L. Fruhling, Lester A. Digman (2000) The Impact Of Electronic Commerce On Business-Level Strategies : Journal of Electronic Commerce Research, VOL. 1, NO. 1, 2000 